\title{
Auricular Pseudocyst Due to Unusual Repetitive Manipulation of the Ears Clinical approach
}

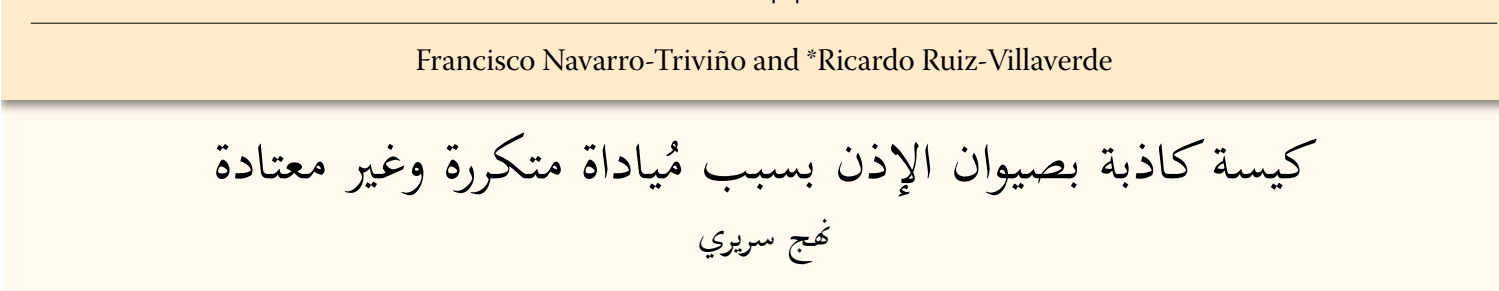

فرانسسكو نافورو-ترايفينو و ريكاردو رويز-فيلا فيردي
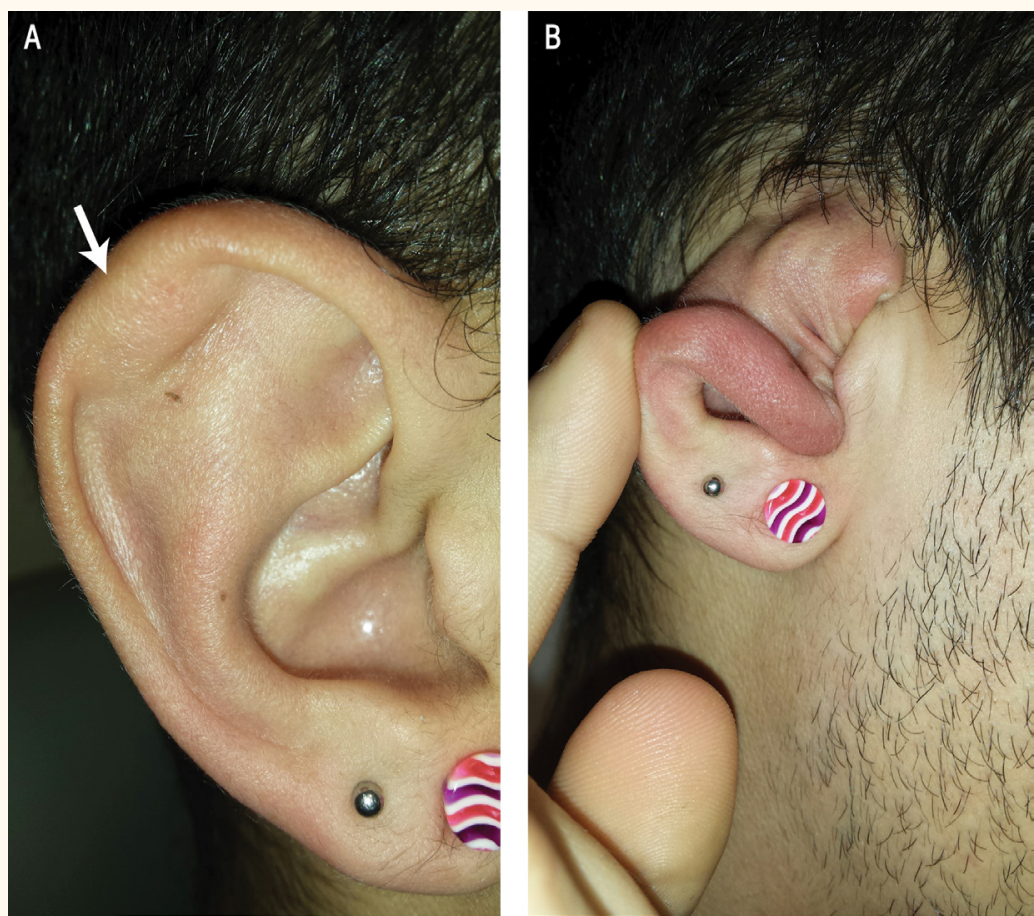

Figure 1: A: Photograph of a well-defined auricular nodular lesion (arrow) on the scaphoid fossa and helix of a 22-yearold man, with no signs of infection or local inflammation. B: Photograph of the unnatural manual placement of the upper third of the helix into the interior of the external auditory canal. The patient reported having routinely performed this action since early childhood.

A 22-YEAR-OLD MAN PRESENTED TO THE Complejo Hospitalario de Granada, Granada, Spain, in 2006 with an asymptomatic nodule in each ear of several years' duration. On physical examination, two well-delimited nodules of semi-solid consistency were observed on the helix and scaphoid fossa of each auricular pavilion [Figure 1A]. There was no evidence of any local infection or inflammation. The patient had no personal or family history of medical interest, such as previous injuries or frequent use of headphones or contact sports. However, he described a history of unusual repetitive manipulation of the ears since early childhood [Figure 1B].

High-frequency ultrasonography of one of the nodules showed an oval cystic lesion with anechoic content and without a capsule or cartilaginous disruption [Figure 2]. Laboratory testing, including blood count, general biochemistry, thyroid profile, uric acid, complement, autoantibody (e.g. anti-nuclear antibody and extractable nuclear antigen antibody) 


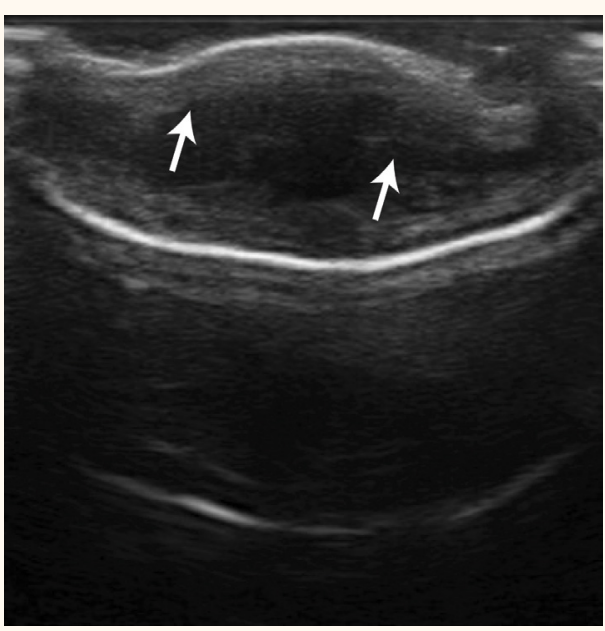

Figure 2: Ultrasonography of the ear of a 22-year-old man showing a hypoechoic cystic lesion without a capsule and with anechoic content (arrows) and poorlydelimited hypoechoic structures compatible with cartilaginous tissue.

and proteinogram tests, indicated no abnormalities. An evaluation of the patient revealed no psychopathological conditions. Histology confirmed that the nodule was an intracartilaginous cyst devoid of epithelial lining and that the pseudocystic space was filled with mucinous material [Figure 3].

Approximately $0.5 \mathrm{~mL}$ of straw-coloured fluid was aspirated from the lesion before injection of $0.5 \mathrm{~mL}$ of a $5 \mathrm{mg} / \mathrm{mL}$ triamcinolone acetonide solution. Subsequently, the ear was covered with gauze which was well taped to the skin, resulting in satisfactory compression of the affected area. The patient was evaluated every two days over a 14-day period to check that necrosis had not developed. There was no evidence of recurrence at a four-month follow-up.

\section{Comment}

An auricular pseudocyst (AP) is a benign asymptomatic non-inflammatory lesion of unknown aetiology and variable size located in the helix or the triangular or scaphoid fossae of the ear., ${ }^{1,2}$ Both unilateral and bilateral APs have previously been described in the literature. ${ }^{2}$ A history of ear-related trauma, frequent use of headphones or contact sports such as rugby have been associated with APs. ${ }^{3}$ The differential diagnosis of this entity includes chondrodermatitis nodularis helicis, epidermal cysts, recurrent perichondritis and rheumatoid nodules. ${ }^{3}$ For injuries affecting the auricle, the differential diagnosis may be challenging; therefore, caution is required so as to subsequently guide appropriate treatment.

Incision and drainage of APs is contraindicated, as there is a local recurrence rate of $100 \%{ }^{4}$ Intra-

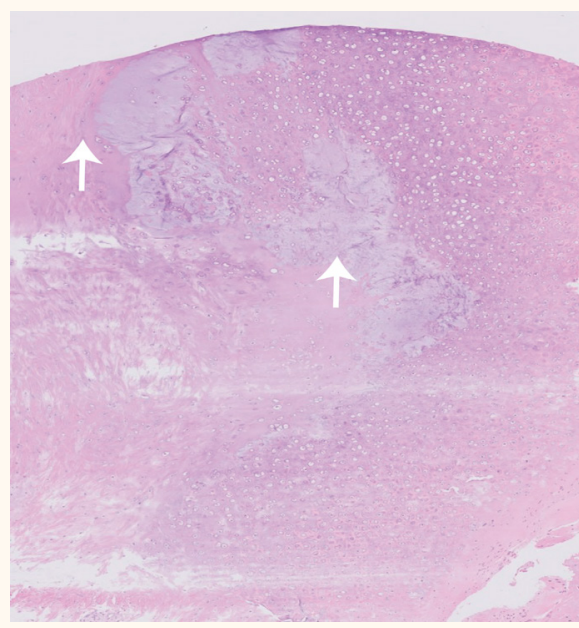

Figure 3: Haematoxylin and eosin stain at $\mathrm{x} 4$ magnification showing an intracartilaginous cyst devoid of epithelial lining with mucinous material (arrows) filling the pseudocystic space.

lesional injections of triamcinolone or sclerosing drugs, such as tetracycline or trichloroacetic acid, are considered the optimal choice of treatment. ${ }^{4-6}$ Surgical excision with local compression (i.e. using shirt buttons or mouldable thermoplastic tablets) also offers effective cosmetic and functional results. ${ }^{6,7}$ Overall, unnecessary procedures should be avoided so as to circumvent unanticipated complications, such as infection, auricular chondritis or related deformities. ${ }^{8}$

\section{References}

1. Cohen V, Fortier-Riberdy G, Saliba I, Davar S. A case of auricular pseudocyst. J Cutan Med Surg 2016; 20:573-4. doi: $10.1177 / 1203475416651604$.

2. Tupker R, Toonstra J. Auricular pseudocyst in a woman. BM) Case Rep 2013; 2013:bcr2013010157. doi: 10.1136/bcr-2013010157.

3. Kallini JR, Cohen PR. Rugby injury-associated pseudocyst of the auricle: Report and review of sport-associated dermatoses of the ear. Dermatol Online J 2013; 19:11.

4. Miyamoto H, Oida M, Onuma S, Uchiyama M. Steroid injection therapy for pseudocyst of the auricle. Acta Derm Venereol 1994; 74:140-2.

5. Kim TY, Kim DH, Yoon MS. Treatment of a recurrent auricular pseudocyst with intralesional steroid injection and clip compression dressing. Dermatol Surg 2009; 35:245-7. doi: $10.1111 /$ j.1524-4725.2008.34416.x.

6. Cohen PR, Katz BE. Pseudocyst of the auricle: Successful treatment with intracartilaginous trichloroacetic acid and button bolsters. J Dermatol Surg Oncol 1991; 17:255-8. doi: 10.1111/j.1524-4725.1991.tb03639.x.

7. Kindem S, Sanmartin C, Serra-Guillén C, Guillén C. Compression treatment of auricular pseudocyst with thermoplastic splinting (Aquaplast $^{(B)}$ ). Actas Dermosifiliogr 2013; 104:357-9. doi: 10.1016 /j.adengl.2012.07.025.

8. Blasco-Morente G, Arias-Santiago S, Garrido-Colmenero C, Pérez-López I. Sonographic features of auricular pseudocyst. Actas Dermosifiliogr 2015; 106:840. doi: 10.1016/j.ad.2015. 03.009 . 